\title{
Occupational exposure to formaldehyde and risk of non hodgkin lymphoma: a meta-analysis
}

\author{
Simona Catalani ${ }^{1 *}{ }^{*}$, Francesca Donato $^{2 \dagger}$, Egidio Madeo ${ }^{1}$, Pietro Apostoli ${ }^{1}$, Giuseppe De Palma ${ }^{1}$, Enrico Pira ${ }^{2}$, \\ Kenneth A. Mundt ${ }^{3}$ and Paolo Boffetta ${ }^{4,5}$
}

\begin{abstract}
Background: Formaldehyde, a widely used chemical, is considered a human carcinogen. We report the results of a meta-analyses of studies on the relationship between occupational exposure to formaldehyde and risk of nonHodgkin lymphoma (NHL).

Methods: We performed a systematic review and meta-analysis according to international guidelines and we identified 12 reports of occupational populations exposed to formaldehyde. We evaluated inter-study heterogeneity and we applied a random effects model. We conducted a cumulative meta-analysis and a meta-analysis according to estimated average exposure of each study population.

Results: The meta-analysis resulted in a summary relative risk (RR) for NHL of 0.93 (95\% confidence interval 0.831.04). The cumulative meta-analysis suggests that higher RRs were detected in studies published before 1986, while studies available after 1986 did not show an association. No differences were found between different levels of occupational exposure.

Conclusions Notwithstanding some limitations, the results of this meta-analysis do not support the hypothesis of an association between occupational exposure to formaldehyde and risk of NHL.
\end{abstract}

Keywords: Non-Hodgkin lymphoma, Formaldehyde, Cancer, Meta-analysis

\section{Background}

Formaldehyde is a high-volume industrial chemical with 5 million tons produced annually in the United States (US). Major occupational sources of exposure include manufacturing of resins for wood products, furniture and fixtures, wearing apparel and textiles, chemicals and plastic products;

occupational exposure to formalin, a solution of formaldehyde in water, occurs in several service industries, including medical, dental and veterinary [1-3].

Exogenous formaldehyde is rapidly metabolized at the site of entry (typically the upper respiratory tract). Formaldehyde is also produced endogenously and is an

\footnotetext{
* Correspondence: simonacatalani@tiscali.it

† Simona Catalani and Francesca Donato contributed equally to this work.

${ }^{1}$ Department of Medicine and Surgery Specialties, Radiological Sciences and

Public Health University of Brescia, 25133 Brescia, Italy
}

Full list of author information is available at the end of the article essential intermediate in the biosynthesis of purines, thymidine, and various amino acids [4].

Exposure to relatively high concentrations (i.e., longterm exposure to concentrations greater than about 4 ppm) formaldehyde has been shown to cause nasal cancer in animal experiments $[5,6]$, and associations have been reported between occupational exposure to formaldehyde and risk of several types of cancer [7-9].

Human cancer risks associated with formaldehyde exposure have been investigated in occupational cohorts and community-based case-control studies. Occupational cohort studies generally provide higherquality evidence than population-based case-control studies, primarily due to better exposure data and a greater potential for higher and more sustained levels of exposure [10].

In 2006 the International Agency for Research on Cancer (IARC) concluded that there was sufficient

(c) The Author(s). 2019 Open Access This article is distributed under the terms of the Creative Commons Attribution 4.0 International License (http://creativecommons.org/licenses/by/4.0/), which permits unrestricted use, distribution, and 
evidence in humans for the carcinogenicity of formaldehyde, based on results of epidemiological studies reporting an association with nasopharyngeal cancer; at that time, IARC also concluded that there was "strong but not sufficient evidence for a causal association between leukaemia and occupational exposure to formaldehyde" [2]. In 2009, IARC added leukaemia to the list of neoplasms caused by formaldehyde, although this was determined by a small majority of the Working Group [11]. Subsequently, the National Toxicology Program of the National Institute of Environmental Health Sciences changed the classification of formaldehyde from "anticipated to be carcinogenic in humans" to "known to be a human carcinogen" [3].

Numerous reviews and meta-analyses have focused on associations between formaldehyde and lymphohematopoietic cancer in general or leukemia $[10,12,13]$, but no similar review and meta-analysis has been published on epidemiological studies evaluating exposure to formaldehyde and risk of non-Hodgkin lymphoma (NHL).

NHL is a histologically and genetically heterogeneous group of malignancies originating from $\mathrm{B}$ - and $\mathrm{T}$-cell lineages that account for $2.7 \%$ of the global cancer burden, with important variations in geographic and temporal patterns of incidence $[14,15]$. Known causes of NHL explain only a small proportion of cases which occur globally; these include chemotherapy treatment or severe immune system dysregulation, infection with Epstein-Barr virus, hepatitis $\mathrm{C}$ virus, and Helicobacter pylori, as well as autoimmunity and atopic conditions, high BMI, and tobacco smoking in addition to family history of lymphatic neoplasms [16].

We therefore conducted a systematic review and meta-analysis of epidemiological studies published investigating the association between occupational exposure to formaldehyde and risk of NHL. We excluded studies based on either environmental or dietary exposure to formaldehyde because of lower and less precisely defined exposure levels compared to workplace exposure.

\section{Methods}

The systematic review and meta-analysis were performed according to the guidelines specified in the PRISMA-statement [17]. The methods were documented in a protocol (available upon request); the PRISMA checklist is included in Additional file 1: Table S1.

\section{Literature search and study selection}

We conducted comprehensive literature searches of Scopus and PubMed, up to 12 July 2018; PubMed "related article" links and reference lists of key studies and reviews were used to complement the primary searches. The searches included the keywords ("formaldehyde")
AND ("cancer" OR "neoplasm" OR "lymphoma" OR "non-Hodgkin lymphoma").

To be included in the meta-analysis, studies had to fulfill the following criteria: (i) original reports based on workers exposed to formaldehyde; (ii) studies in which the results were reported for NHL ([ICD-9 codes 200, 202]: lymphosarcoma and reticulosarcoma and other specified malignant tumors of lymphatic tissue; other malignant neoplasms of lymphoid and histiocytic tissue and [ICD-10 codes C82, C85]: follicular lymphoma; other specified and unspecified types of non-Hodgkin lymphoma), alone or with other categories of lymphohematopoietic neoplasms (e.g., Hodgkin lymphoma [ICD-9 code 201] or multiple myeloma [ICD-9 code 203]), excluding leukemia; (iii) studies in which a measure of association between formaldehyde exposure and risk of NHL, expressed either as standardized mortality ratios (SMR), standardized incidence ratios (SIR), proportionate mortality ratio (PMR), relative risk (RR) or odds ratio (OR) either was reported or could be derived from the publication.

Two authors (SC, FD) independently reviewed the list of titles and abstracts, to determine which studies potentially met the inclusion criteria. Duplicates and irrelevant references were eliminated. The final selection was based on the examination of the full text of potentially relevant articles. Cases of disagreement or doubt were resolved with the inclusion of a third author (PB). The search and selection process are shown in Fig. 1.

After reviewing the titles of 3008 articles, we eliminated 2905 that did not appear to be relevant, and reviewed the abstracts of the remaining 103 articles. Review of these led to the elimination of 53 articles that did not meet the inclusion criteria, leaving 50 articles for detailed review. Thirty of the 50 articles subsequently were eliminated because exposure was not clearly defined, or results were reported for all lymphohematopoietic neoplasms combined ([ICD9codes 200-209] malignant neoplasm of lymphatic and hematopoietic tissue). Among the remaining 20 articles, some referred to the same study population; in such cases, we selected the report with the most complete information (i.e., longest follow-up), leaving for the meta-analysis 12 reports of studies of nonoverlapping populations (Table 1) [18-29].

Five of these 12 reports [29-33] were based on a single large cohort study of workers from 10 US plants producing or using formaldehyde. This study was initiated by the US National Cancer Institute (NCI) in the early 1980s in collaboration with the Formaldehyde Institute, and the first results were published in 1986 [30]. We included in the meta-analysis the results of the most recent analysis of this cohort [29]. Similarly, we selected the article by Pinkerton and coworkers (2004) [25], the 


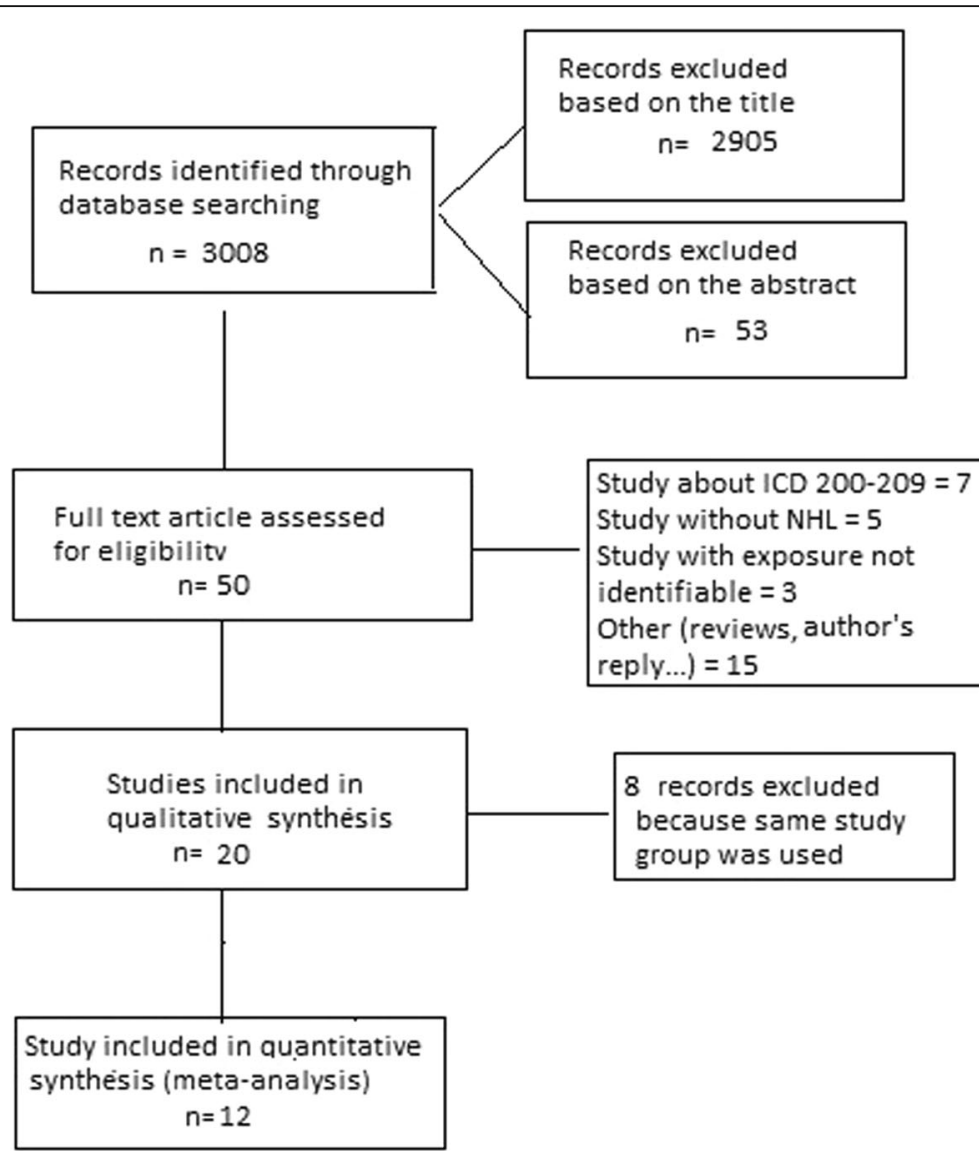

Fig. 1 Flow chart of search and selection of studies included in the review and meta-analysis

most recent of three analyses of a cohort of workers from three garment manufacturing facilities, located in Georgia and Pennsylvania, USA [25, 34, 35], and the article by Coggon and colleagues (2014) [28], the most recent of three articles based on a cohort of workers from six chemical factories in England and Wales [28, 36, 37].

\section{Data extraction}

We extracted key characteristics of each of the studies retained for the meta-analysis (Table 1). We aimed at investigating NHL (i.e., International Classification of Diseases, version 9 (ICD-9) codes 200, 202 and ICD-10 codes C82, C85); however, results from some studies were available only for different disease categories (see Table 1 for details). When results were reported based on different strategies for adjustment for potential confounders, we included the fully adjusted risk estimates. When the data were reported for different levels of exposure, we chose the category at highest exposure.

\section{Data analysis}

We evaluated inter-study heterogeneity using the general variance-based method, and applied a random effects model which incorporates between-study variation into the summary variance estimate to estimate summary RR and 95\% confidence interval (CI) estimates [38].

We conducted sensitivity analyses excluding one study at a time from the meta-analysis, and a cumulative meta-analysis according to the year of publication of the individual studies. Finally, we conducted a meta-analysis according to the type of average exposure level of the workers included in each study, categorized as very low, low and medium-high exposure.

The exposure in each study was classified as very low when the levels of formaldehyde was estimated lower than $10 \mu \mathrm{g} / \mathrm{m}^{3}$, low when it was between 10 and $200 \mu \mathrm{g} / \mathrm{m}^{3}$ and medium-high when it was higher than $100 \mu \mathrm{g} / \mathrm{m}^{3}$.

The classification was made on the basis of the data on exposure levels available from the studies included in the meta-analysis and on the type of industry; it does not aim to be comprehensive, such as the one proposed by IARC [2].

We generated funnel plots of the results included in the meta-analysis and used the test proposed by Egger et al. [39] to assess possible publication bias. 
Table 1 Selected characteristics of studies included in the meta-analysis

\begin{tabular}{|c|c|c|c|c|c|c|c|c|c|c|}
\hline Reference & Country & $\begin{array}{l}\text { Study } \\
\text { design }\end{array}$ & $\begin{array}{l}\text { Study } \\
\text { period* }\end{array}$ & Population & $\begin{array}{l}\text { Levels of } \\
\text { Exposure }\end{array}$ & Outcome & $\begin{array}{l}\mathrm{I} \\
\mathrm{M}\end{array}$ & Obs/Exp & $N^{* *}$ & $\%$ men \\
\hline $\begin{array}{l}\text { Walrath et al., } \\
1983 \text { [18] }\end{array}$ & $\begin{array}{l}\text { USA, New } \\
\text { York }\end{array}$ & $\mathrm{Co}$ & $\begin{array}{l}\text { 1902-1980 / } \\
\text { 1925-1980 } \\
\text { (death) }\end{array}$ & Embalmers & 0.20 to $0.91 \mathrm{ppm}$ & $\begin{array}{l}\text { ICD-8200; } \\
\text { 202,203 }\end{array}$ & $M$ & $11 / 9.6$ & n.a. & 100 \\
\hline $\begin{array}{l}\text { Walrath et al., } \\
1984 \text { [19] }\end{array}$ & $\begin{array}{l}\text { USA, } \\
\text { California }\end{array}$ & Co & $\begin{array}{l}\text { 1916-1978/ } \\
\text { 1925-80 } \\
\text { (death) }\end{array}$ & Embalmers & 0.2 and $0.9 \mathrm{ppm}$ & $\begin{array}{l}\text { ICD-8200; } \\
202,203 \\
208209\end{array}$ & M & $7 / 6.1$ & n.a. & 100 \\
\hline $\begin{array}{l}\text { Stroup et al., } \\
1986[20]\end{array}$ & USA & Co & 1888-1969 & Anatomist & $\begin{array}{l}\text { cumulative } \\
\text { exposure }\end{array}$ & $\begin{array}{l}\text { ICD-8200; } \\
\text { 202, 203, } \\
\text { 208-209 }\end{array}$ & M & $8 / 5.9$ & $\begin{array}{l}2 \%+3 \% \\
\text { migrated }\end{array}$ & 100 \\
\hline $\begin{array}{l}\text { Partanen et al., } \\
1993 \text { [21] }\end{array}$ & Finland & $\begin{array}{l}\text { case-referent } \\
\text { nested }\end{array}$ & 1957-1982 & Wood Industry & $\begin{array}{l}\text { reconstructed } \\
\text { using a plant/ } \\
\text { period-specific } \\
\text { job exposure }\end{array}$ & $\begin{array}{l}\text { ICD-7200, } \\
202\end{array}$ & M & 4/n.a. & n.a. & \\
\hline $\begin{array}{l}\text { Hansen et al., } \\
1995 \text { [22] }\end{array}$ & Denmark & $\begin{array}{l}\text { record } \\
\text { linkage }\end{array}$ & 1970-1984 & $\begin{array}{l}\text { Facilities that used } \\
\text { or manufactured } \\
>1 \mathrm{~kg} \text { per year of } \\
\text { formaldehyde }\end{array}$ & $\begin{array}{l}\text { Job title in } \\
\text { formaldeide } \\
\text { associated } \\
\text { facilities }\end{array}$ & $\begin{array}{l}\text { ICD-7200, } \\
202\end{array}$ & । & $32 / 37.5$ & & \\
\hline $\begin{array}{l}\text { Stellman et al., } \\
1998[23]\end{array}$ & USA & Co & $\begin{array}{l}\text { 1982--f.up } \\
1988\end{array}$ & $\begin{array}{l}\text { Wood Dust } \\
\text { Exposure }\end{array}$ & check.off list & $\begin{array}{l}\text { ICD-9200, } \\
202\end{array}$ & M & 11/n.a. & $2 \%$ & 100 \\
\hline $\begin{array}{l}\text { Band et al., } \\
1997 \text { [24] }\end{array}$ & Canada & Co & 1950-1992 & $\begin{array}{l}\text { pulp and paper } \\
\text { mill }\end{array}$ & - & ICD-9200, 202 & M & 35/n.a. & $10 \%$ & 100 \\
\hline $\begin{array}{l}\text { Pinkerton et al., } \\
2004 \text { [25] }\end{array}$ & USA & Co & $\begin{array}{l}\text { 1955-f.up } \\
1998\end{array}$ & $\begin{array}{l}3 \text { garment } \\
\text { industries }\end{array}$ & $\begin{array}{l}\text { personnel } \\
\text { records of } \\
\text { exposure }\end{array}$ & $\begin{array}{l}\text { ICD-9200; } \\
\text { 202,203 }\end{array}$ & M & 33/n.a. & n.a & 18.3 \\
\hline $\begin{array}{l}\text { Meyers et al., } \\
2013 \text { [26] }\end{array}$ & USA & Co & $\begin{array}{l}1955 / 59- \\
2008\end{array}$ & $\begin{array}{l}\text { formaldehyde } \\
\text { resins }\end{array}$ & $\begin{array}{l}\text { campaign of } \\
\text { personal sampling }\end{array}$ & $\begin{array}{l}\text { ICD-10 } \\
\text { (C46.3,C82-C85, } \\
\text { C88.0,C88.3, } \\
\text { C91.4,C96) }\end{array}$ & M & 66/n.a & 1.1 & 18 \\
\hline $\begin{array}{l}\text { Pira et al., } \\
2014 \text { [27] }\end{array}$ & Italy & Co & $\begin{array}{l}1930-1966 \text { or } \\
1934-58 \text { until } \\
2004\end{array}$ & $\begin{array}{l}\text { laminated plastic } \\
\text { workers }\end{array}$ & $\begin{array}{l}\text { time of } \\
\text { employment }\end{array}$ & ICD-9200-202 & M & $4 / 5.4$ & 3.1 & 81 \\
\hline $\begin{array}{l}\text { Coggon et al., } \\
2014 \text { [28] }\end{array}$ & UK & Co & $1941-2012$ & chemical workers & $\begin{array}{l}\text { recorded titles } \\
\text { of jobs }\end{array}$ & ICD-9200,202 & M & $13 / 14.4$ & & 100 \\
\hline $\begin{array}{l}\text { Checkoway } \\
\text { et al., } 2015 \\
\text { [29] }\end{array}$ & USA & Co & $\begin{array}{l}1930-1966 \text { or } \\
1934-58 \text { until } \\
2004\end{array}$ & $\begin{array}{l}\text { manufacturersor } \\
\text { users of } \\
\text { formaldehyde, }\end{array}$ & $\begin{array}{l}\text { estimated for } \\
\text { each job from } \\
\text { individual work } \\
\text { histories }\end{array}$ & ICD-8200,202 & M & 94/n.a. & & 81.8 \\
\hline
\end{tabular}

NR not relevant, NA not available, Co cohort study, CC case-control study, NCC case-control study nested in a cohort, I incidence, $M$ mortality, $N$ number of cohort members (cohort studies) or number of cases (case-control studies), NHL non-Hodgkin lymphoma, ICD International Classification of Diseases

\section{Results}

The meta-analysis comprised results from 12 independent studies [18-29], only the study by Hansen et al. [22] analyzed the incidence of NHL, while the remaining studies were based on mortality data. Overall, these studies included a total of $318 \mathrm{NHL}$ cases or deaths.

Risk estimates for NHL (ICD-9200,202) were reported in 7 studies [21-24, 26, 28, 29]; in 5 additional studies [18-20, 25, 27] we combined, using a fixed-effect model, the results calculated for different ICD-9 categories, as shown in Table 1.

The results of the individual studies are reported in Fig. 2, together with the results of the main metaanalysis, that yielded a summary RR of 0.93 (95\% CI 0.83-1.04). There was no evidence of heterogeneity between studies $(p=0.88)$. The only study examining incident cases of NHL reported an SIR of 0.90 (0.60-1.20), nearly identical to the summary RR [22].

The NCI cohort [29] contributed $41.93 \%$ of the total weight of the meta-analysis, while each of the other studies contributed less than $13 \%$ of the total weight. The exclusion of the NCI cohort resulted in a meta-RR equal to 1.01 (0.95 CI 0.87-1.15). The exclusion of each of the other studies one at a time had a lesser effect, resulting in meta-RRs ranging from 0.91 to 0.94 .

We conducted a further analysis of studies based on outcome definition restricted to ICD-9 codes 200,202, that resulted in a meta-RR of 0.92 (95\% CI, 0.80-1.03) while the meta-RR based on the other five study with mixed definitions of outcome was 1.01 (95\% CI 0.75-1.27) [ 21-24, 26, 28-29]. 


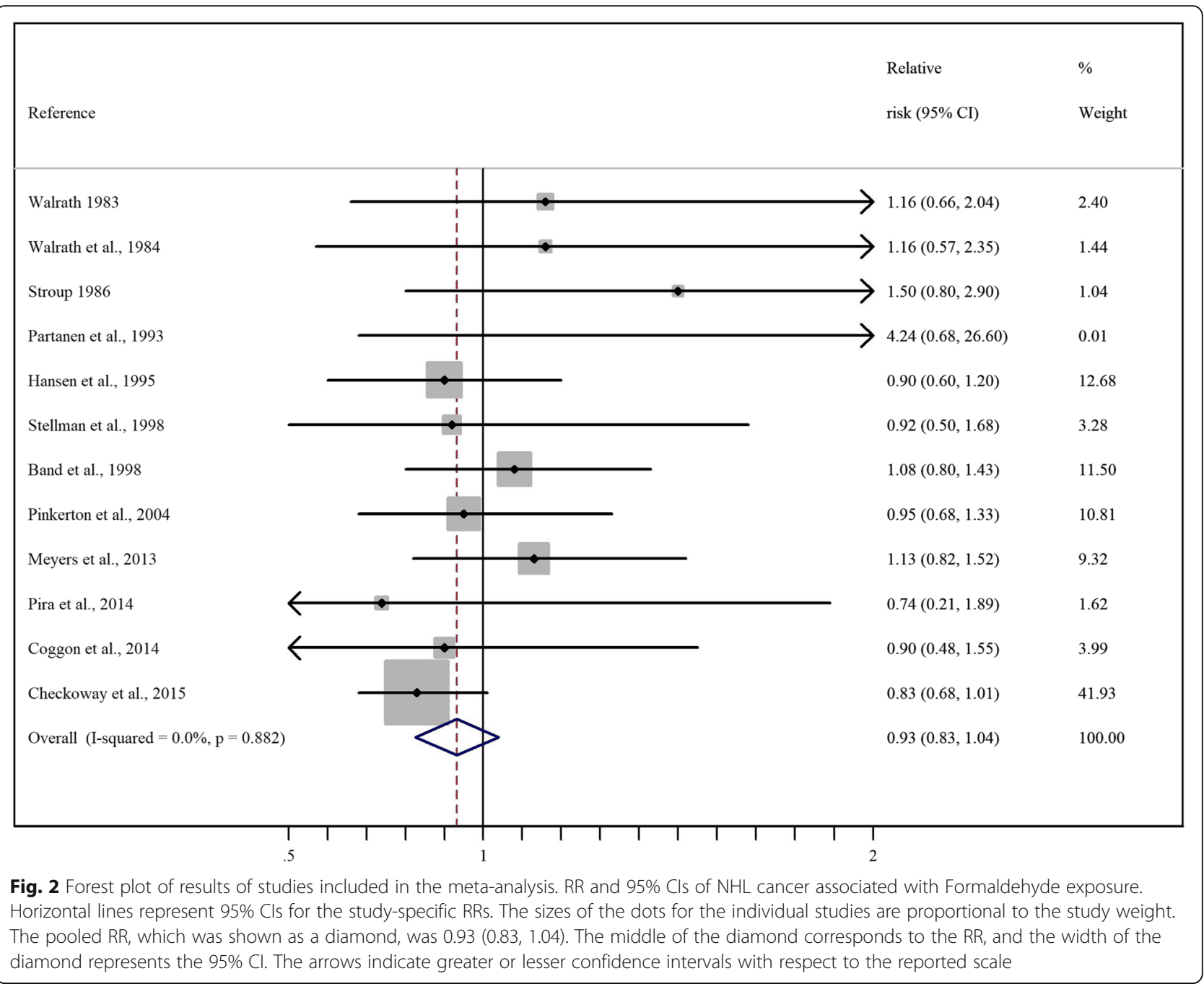

The cumulative meta-analysis suggests that slightly higher RRs (all with $\mathrm{RR} \leq 1.16$ and none statistically significantly elevated) were detected based on the three earliest studies (published before 1986), while the metaRR of studies available after 1986 ranged from 0.85 to 0.95 without a clear trend during this period (Fig. 3).

In the analysis according to level of exposure made on the basis of the data on exposure levels available from the studies included in the meta-analysis and on the type of industry, we classified as "very low" exposure the studies conducted in laminated plastic manufacturing, where formaldehyde is a by-product released from resins in the phase of machining [27], in pulp and paper mills [24] and in 265 Danish companies in which more than $1 \mathrm{~kg}$ of formaldehyde was used or manufactured per employee per year [22]. The meta-RR of these studies with very low exposure was 0.97 (95\% CI 0.76-1.18).

Exposure was classified as "low" in studies conducted in the wood industry $[21,23]$ and in garment manufacturing facilities [26, 27]. The meta-RR of these studies was 1.02 (95\% CI 0.80-1.24). Finally, the exposure was classified as "medium-high" in studies conducted among embalmers and anatomists [18-20], in 10 US plants producing or using formaldehyde [ 29](manufacture of formaldehyde, formaldehyde-based resins, or molding compounds, or use of formaldehyde-based resins or molding compounds, including molded plastic products, decorative laminates, photographic film, and plywood) and in six British chemical factories at a time when formaldehyde was produced or used [28]. The meta-RR of these studies was 0.87 (95\% CI 0.72-1.02). There was no evidence of heterogeneity between the three groups of studies ( $p$-heterogeneity between summary risk estimates 0.43 ).

The visual assessment of the funnel plot (Fig. 4) and the result of the Egger's test $(P=0.056)$ suggested the possibility of publication bias, with negative results of small studies apparently being missing. 


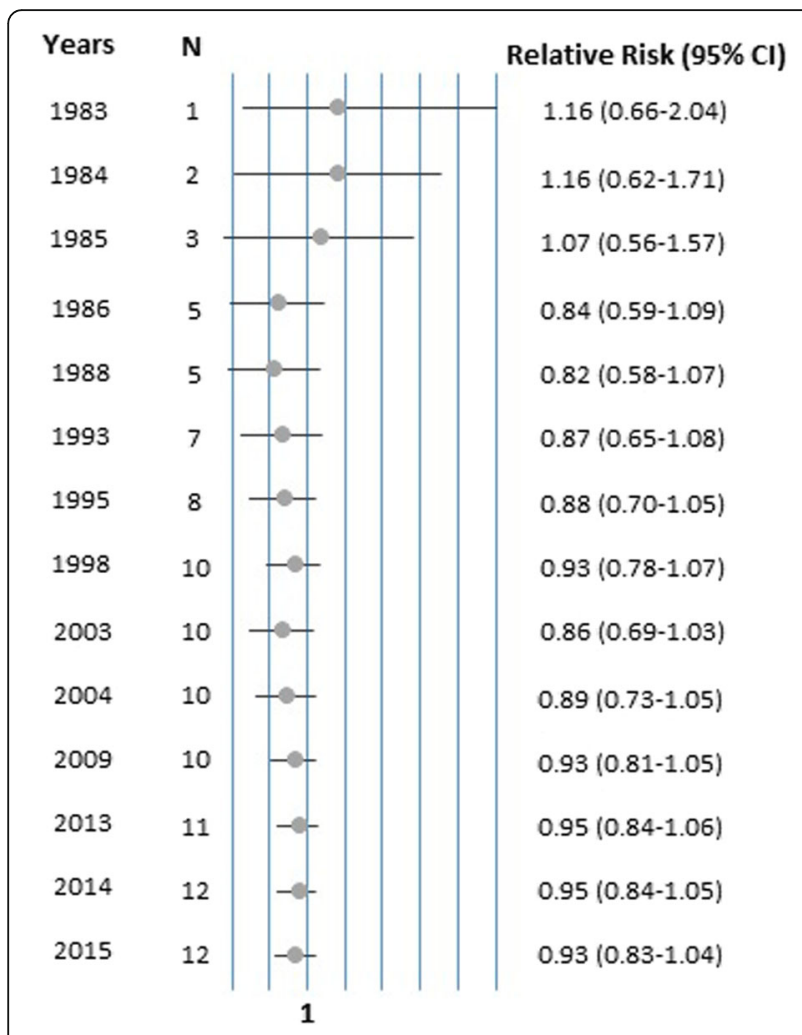

Fig. 3 Cumulative meta-analysis according to the year of publication of the individual studies. The circles represent the RRs of the studies conducted in different years, the lines are the respective 95\% Cls

Some studies carried out an assessment of the risk of NHL in relation to time-related indicators of exposure (Additional file 1: Table S2).

Results by duration of exposure were reported in a few studies. In the US garment workers' study [26], the SMR for NHL for exposure > 10 years was 1.21 (95\% CI $0.69-$ 1.97), while in one the analyses of the NCI study [32] the RR for $>15$ years of exposure was 0.98 (95\% CI 0.49-1.96) and in the study of laminated plastic workers from Italy [26] the SMR for > 20 years of exposure was 0.76 .

Four studies reported results by time of first formaldehyde exposure [26, 27, 35, 37]. In the study of US garment workers [26], the SMR for workers first employed before 1963 was 1.19 (95\% CI 0.82-1.69), for workers first employed between 1963 and 1971 the SMR was 1.11 (95\% CI 0.53-2.04) and for workers first employed after 1971 the SMR was 0.65 (95\% CI 0.08-2.33) (26). In a subsequent analysis of this study [34], the SMR for other lymphatic and hematopoietic neoplasms, including NHL, was highest (SMR 1.64; 95\% CI not available) among workers first exposed during 1955-1962, when potential formaldehyde exposure was highest. In the study of Italian laminated plastic workers [27] there was no trend by period of first employment. In the study of UK chemical workers [37], mortality for NHL was higher in worker employed after 1964 than in workers employed before that.

Analyses by cumulative exposure to formaldehyde were reported in several articles based on the NCI cohort study $[30,32,33]$. In particular, the RR for cumulative exposure above 5.5 ppm-years was 0.91 (95\% CI 0.54-1.52), with no trend $(p>0.5)$ [33]. Analyses according to peak exposure in the same cohort also failed to detect a dose-response relationship with risk of NHL $[32,33]$.

\section{Discussion}

Our meta-analysis of studies of individuals exposed to formaldehyde provided no evidence of an increased risk of NHL overall (RR $0.93 ; 95 \%$ CI $0.83-1.04$ ) or by

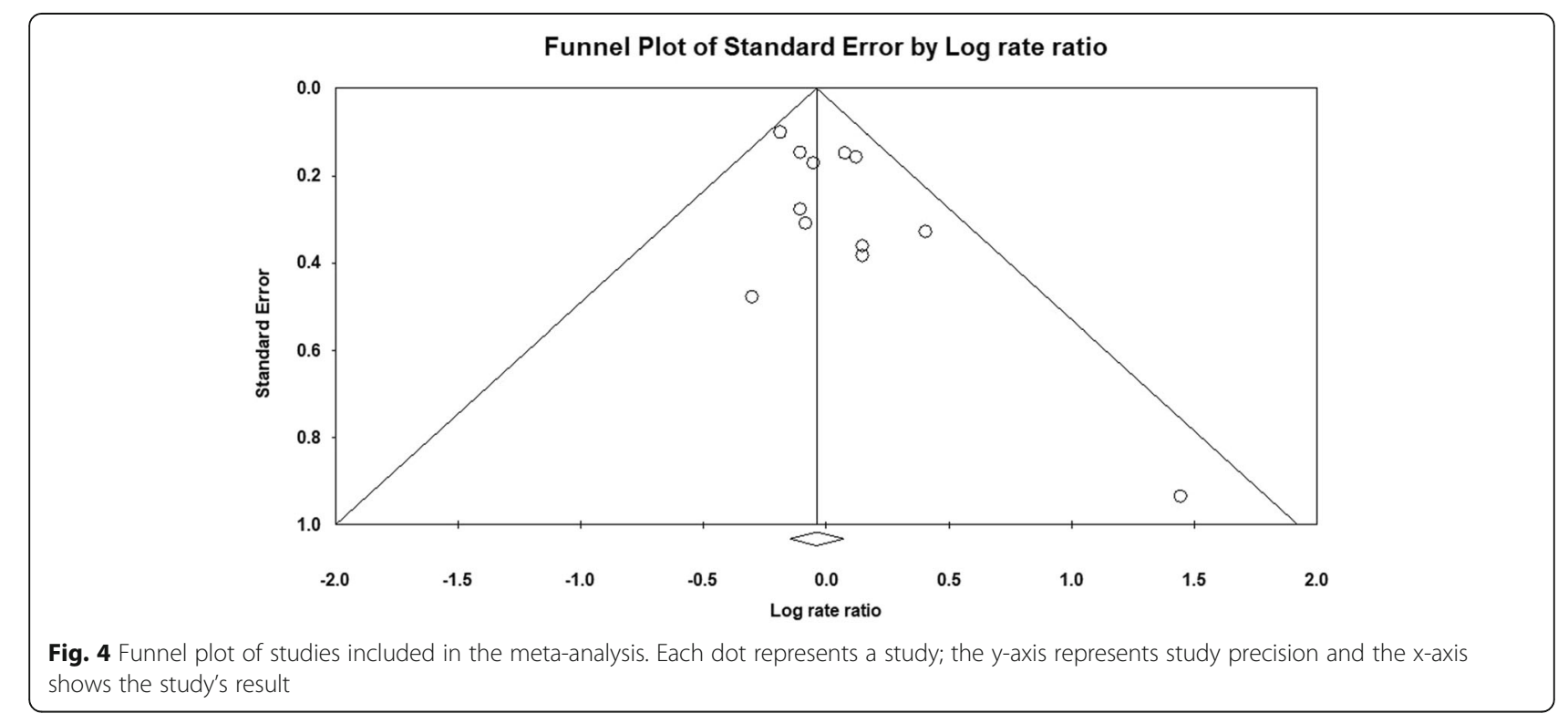


various exposure categories or characteristics. The metaanalysis comprised results from 11 independent studies with data of mortality of NHL and one that analyzed the incidence of NHL. Study populations were employed in laminated plastic manufacture, in pulp and paper mills, in the wood industry, in garment manufacturing facilities, among embalmers and anatomists and different plants producing or using formaldehyde; no differences of risk were found in different types of exposure. The limited data on time-related indicators of exposure did not find any trend indicating an increased risk of mortality for NHL with longer duration of exposure, longer "time since first exposure" or higher exposure level.

Because of its high water solubility and reactivity, formaldehyde is expected to exert its toxicity predominantly at the site of entry. As a result of its reactivity in target tissues, formaldehyde causes local irritation, acute and chronic toxicity and has genotoxic and cytotoxic properties [40].

Genotoxicity may play an important role in the carcinogenicity of formaldehyde in nasal tissues in humans, in addition, cellular replication in response to formaldehyde-induced cytotoxicity may promote the carcinogenic response [41]. There is controversy on the ability of formaldehyde to cause leukemia [42]. Three mechanisms were suggested by which formaldehyde could act as a leukemogenic: (i) by damaging stem cells in the bone marrow directly (ii) by damaging haematopoietic stem/progenitor cells circulating in the peripheral blood, and (iii) by damaging the primitive pluripotent stem cells present within the nasal turbinates or olfactory mucosa [13, 43-45].

NHL include a diverse group of neoplasms derived from T- and B-cells and their precursors in the lymphoid system; a genotoxic action on circulating stem cells would be consistent with the possibility that formaldehyde is a cause of lymphatic neoplasms, and one would expect that the mucosa-associated lymphatic tissue in the nasal region would be particularly at risk. There is also recognition of their inter-relatedness of these neoplasms through a common stem cell, and the malignant transformation might take place during various stages of the differentiation and maturation process of the precursor cells in bone marrow [46]. Evidence suggests that an underlying cytogenetic abnormality in an early precursor cell predisposes to subsequent mutations leading to a specific lymphohematopoietic neoplasm [47]. Assuming that the leukemogenic mechanisms mentioned above have a biologic plausibility, the possibility of a mutagenic effect of formaldehyde on circulating lymphocytes or local lymphatic tissue could not be ruled out; however, evidence on how this might occur currently is lacking.

Based on these hypothesis we decided to conduct a review of the relevant epidemiological studies investigating the relationship between occupational formaldehyde exposure and risk of NHL, but we found no evidence of an increased risk of this group of neoplasms in diverse groups of workers exposed to formaldehyde.

The main strengths of our study were the exhaustive nature of the literature search, and the focus on results with a specific definition of the phenotype that led to the exclusion of the studies that analyzed all lymphohematopoietic neoplasms (ICD 200-209), or other combinations including leukemia.

Limitations of our review reflect those of the available studies. They include the lack of quantitative assessment of exposure in most studies and the heterogeneity of the occupational exposure circumstances. We aimed at addressing the latter issue by categorizing the studies according to level of exposure, and found no difference between the groups. The cumulative meta-analysis suggests a weakly higher RR in the first three studies compared to more recent studies. Explanations for this pattern might include a higher intensity of exposure to formaldehyde (which assumes a causal relationship that is not apparent) or more likely by a greater opportunity for bias in the earliest studies. The analysis of publication bias further supports the conclusion of no association between formaldehyde exposure and risk of NHL.

Additional evidence is provided by a large, casecontrol study that was conducted in Montreal, Canada, during 1979-1985 [48]. This study included 3723 male cases of multiple types of cancer, including 215 cases of NHL, who were compared to 2357 cases of other cancers, and to 533 population controls. Based on detailed occupational interviews, a team of experts assessed exposure to 294 agents, including formaldehyde, by examining each work history and rating each job on a 3-point scale with regard to their confidence that exposure had actually occurred, the frequency of exposure, and the relative concentration level. Exposure was defined as 'substantial' when it lasted for more than 5 years at medium or higher level of frequency and concentration, and with probable or definite confidence by the experts. The prevalence of ever-exposure to formaldehyde was $15 \%$; main occupations that included exposed subjects were carpenters and textile workers. The results were adjusted for age, ethnicity, socioeconomic status, and self/proxy status of the respondent. The OR of NHL for ever-exposure to formaldehyde was $0.8(95 \% \mathrm{CI}$, derived from data reported in the publication, 0.61.2; 28 exposed cases); that for 'substantial' exposure was 1.2 (95\% CI, derived from data reported in the publication, $0.5-2.7 ; 6$ cases). These results were not included in the meta-analysis because the study did not meet the inclusion criteria; however, they are consistent with those of the meta-analysis in showing 
that formaldehyde exposure is not associated with increased risk of NHL.

\section{Conclusion}

In conclusion, we found no indication of any association between various indicators of occupational exposure to formaldehyde and risk of NHL.

\section{Supplementary information}

Supplementary information accompanies this paper at https://doi.org/10. 1186/s12885-019-6445-Z

Additional file 1: Table S1. PRISMA checklist. Table S2. Assessment of the risk of $\mathrm{NHL}$ in relation to time-related indicators of exposure. Figure S1. Results of meta-analysis by level of exposure.

\section{Abbreviations}

BMI: Body mass index; Cl: Confidence interval; IARC: International Agency for Research on Cancer; NHL: Non-Hodgkin lymphoma; OR: Odds ratio; PMR: Proportionate mortality ratio; RR: Relative risk; SIR: Standardized incidence ratios; SMR: Standardized mortality ratios

\section{Acknowledgements}

Not applicable.

\section{Authors' contribution}

Conception and design: PB, EP, PA. KAM. Development of methodology: SC, FD, PB. Acquisition of data: SC, FD, EM, PB, Statistical analysis: SC, FD, PB. Drafting of manuscript: SC, FD, EM, PB. Critical review of the manuscript: EM, EP, PA, GDP, KAM. Study supervision: PB, EP, PA, GDP, KAM. The final version of the manuscript was approved by all authors.

\section{Funding}

No funding was received.

\section{Availability of data and materials}

The study was based entirely on previously published data. Supplementary information is available at the BMC cancer's website.

\section{Ethics approval and consent to participate}

As a systematic review and meta-analysis, no ethical approval or consent to participate was required.

\section{Consent for publication \\ "Not applicable".}

\section{Competing interests}

PB and KAM provide scientific consulting services to the Formaldehyde Panel Science Committee of the American Chemical Council and to Hexion, Inc. on matters unrelated to the specific topic of the present work. The other authors declare no competing interests.

\section{Author details}

'Department of Medicine and Surgery Specialties, Radiological Sciences and Public Health University of Brescia, 25133 Brescia, Italy. ${ }^{2}$ Department of Public Health and Pediatric Sciences, University of Turin, Turin, Italy. ${ }^{3}$ Cardno ChemRisk, Boston, MA, USA. ${ }^{4}$ Tisch Cancer Institute, Icahn School of Medicine at Mount Sinai, New York, NY, USA. ${ }^{5}$ Department of Medical and Surgical Sciences, University of Bologna, Bologna, Italy.

Received: 13 February 2019 Accepted: 9 December 2019

Published online: 23 December 2019

\section{References}

1. Agency for Toxic Substances and Disease Registry (ATSDR). Toxicological profile for formaldehyde. Atlanta: U.S. Department of Health and Human
Services; 1999. Available at http://www.atsdr.cdc.gov/toxprofiles/tp111.pdf. Accessed Jan 2019

2. International Agency for Research on Cancer (IARC). IARC monographs on the evaluation of carcinogenic risks to humans. Formaldehyde, 2Butoxyethanol and 1-tert-Butoxypropan-2-ol, Vol. 88. Lyon: International Agency for Research on Cancer; 2006. p. 39-325.

3. National Toxicology Program (NTP). Report on carcinogens. 14th ed. Research Triangle Park: U.S. Department of Health and Human Services, Public Health Service; 2016. Available at https://ntp.niehs.nih.gov/go/roc14 Accessed Jan 2019.

4. Neuberger A. The metabolism of glycine and serine. Compr Biochem. 1981; 257-303.

5. Kerns WD, Pavkov KL, Donofrio DJ, Gralla EJ, Swenberg JA. Carcinogenicity of formaldehyde in rats and mice after long-term inhalation exposure. Cancer Res. 1983:43:4382.

6. Kamata E, Nakadate M, Uchida O, Ogawa Y, Suzuki S, Kaneko T, et al. Results of a 28-month chronic inhalation toxicity study of formaldehyde in male fisher-344 rats. J Toxicol Sci. 1997;22:239.

7. Bachand AM, Mundt DJ, Montgomery RR. Epidemiological studies of formaldehyde exposure and risk of leukemia and nasopharyngeal cancer: a meta-analysis. Crit Rev Toxicol. 2010;40(2):85-100.

8. Bosetti C, McLaughlin JK, Tarone RE, Pira E, La Vecchia C. Formaldehyde and cancer risk: a quantitative review of cohort studies through 2006. Ann Oncol. 2008;19:29.

9. Schwilk E, Zhang L, Smith MT, Smith AH, Steinmaus C. Formaldehyde and leukemia: an updated mete-analysis and evaluation of bias. J Occup Environ Med. 2010;52:878.

10. Checkoway H, Boffetta P, Mundt DJ, Mundt KA. Critical review and synthesis of the epidemiologic evidence on formaldehyde exposure and risk of leukemia and other lymphohematopoietic malignancies. Cancer Causes Control. 2012;23:1747.

11. International Agency for Research on Cancer (IARC). IARC monographs on the evaluation of carcinogenic risks to humans. Chemical agents and related occupations; Vol $100 \mathrm{~F}$, A review of human carcinogen. Lyon: International Agency for Research on Cancer; WHO; 2012. p. 401-30.

12. Collins JJ, Lineker GA. A review and meta-analysis of formaldehyde exposure and leukemia. Regul Toxicol Pharmacol. 2004;40:81.

13. Zhang L, Steinmaus C, Eastmond DA, Xin XK, Smith MT. Formaldehyde exposure and leukemia: a new meta-analysis and potential mechanisms. Mutat Res. 2009:681:150

14. Roman E, Smith AG. Epidemiology of lymphomas. Histopathology. 2011;58:4.

15. Morton LM, Wang SS, Devesa SS, Hartge P, Weisenburger DD, Linet MS. Lymphoma incidence patterns by WHO subtype in the United States, 19922001. Blood. 2006;107:265.

16. Alexander DD, Mink PJ, Adami HO, Chang ET, Cole P, Mandel JS, Trichopoulos D. The non-Hodgkin lymphomas: a review of the epidemiologic literature. Int J Cancer. 2007:120:1.

17. Liberati A, Altman DG, Tetzlaff J, Mulrow C, Gøtzsche PC, loannidis JP, et al The PRISMA statement for reporting systematic reviews and meta-analyses of studies that evaluate health care interventions: explanation and elaboration. J Clin Epidemiol. 2009:62:e1.

18. Walrath J, Fraumeni JF Jr. Mortality patterns among embalmers. Int J Cancer. 1983:31:407.

19. Walrath J, Fraumeni JF Jr. Cancer and other causes of death among embalmers. Cancer Res. 1984:44:4638.

20. Stroup NE, Blair A, Erikson GE. Brain cancer and other causes of death in anatomists. J Natl Cancer Inst. 1986;77:1217.

21. Partanen T, Kauppinen T, Luukkonen R, Hakulinen T, Pukkala E. Malignant lymphomas and leukemias, and exposures in the wood industry: an industrybased case-referent study. Int Arch Occup Environ Health. 1993;64:593.

22. Hansen J, Ølsen JH. Formaldehyde and cancer morbidity among male employees in Denmark. Cancer Causes Control. 1995;6:354

23. Stellman SD, Demers PA, Colin D, Boffetta P. Cancer mortality and wood dust exposure among participants in the American Cancer Society Cancer prevention study-II (CPS-II). Am J Ind Med. 1998;34:229.

24. Band PR, Le ND, Fang R, Threlfall WJ, Astrakianakis G, Anderson JTL, et al. Cohort mortality study of pulp and paper mill workers in British Columbia, Canada. Am J Epidemiol. 1997;146:186.

25. Pinkerton LE, Hein MJ, Stayner LT. Mortality among a cohort of garment workers exposed to formaldehyde: an update. Occup Environ Med. 2004;61:193. 
26. Meyers AR, Pinkerton LE, Hein MJ. Cohort mortality study of garment industry workers exposed to formaldehyde: update and internal comparisons. Am J Ind Med. 2013;56:1027.

27. Pira E, Romano C, Verga F, La Vecchia C. Mortality from lymphohematopoietic neoplasms and other causes in a cohort of laminated plastic workers exposed to formaldehyde. Cancer Causes Control. 2014;25:1343.

28. Coggon D, Ntani G, Harris EC, Palmer KT. Upper airway Cancer, myeloid leukemia, and other cancers in a cohort of British chemical workers exposed to formaldehyde. Am J Epidemiol. 2014;179:1301.

29. Checkoway H, Dell LD, Boffetta P, Gallagher AE, Crawford L, Lees PS, et al. Formaldehyde exposure and mortality risks from acute myeloid leukemia and other Lymphohematopoietic malignancies in the US National Cancer Institute cohort study of Workers in Formaldehyde Industries. J Occup Environ Med. 2015;57:785.

30. Blair A, Stewart P, O'Berg M, Gaffey W, Walrath J, Ward J, et al. Mortality among industrial workers exposed to formaldehyde. J Natl Cancer Inst. 1986;76:1071.

31. Dosemeci M, Blair A, Stewart PA, Chandler J, Trush MA. Mortality among industrial workers exposed to phenol. Epidemiology. 1991;2:188.

32. Hauptmann M, Lubin JH, Stewart PA, Hayes RB, Blair A. Mortality from lymphohematopoietic malignancies among workers in formaldehyde industries. J Natl Cancer Inst. 2003:95:1615.

33. Beane Freeman LE, Blair A, Lubin JH, Stewart PA, Hayes RB, Hoover RN, et al. Mortality from Lymphohematopoietic malignancies among Workers in Formaldehyde Industries: the National Cancer Institute cohort. J Natl Cancer Inst. 2009:101:751.

34. Stayner L, Smith AB, Reeve G, Blade L, Elliott L, Keenlyside R, et al. Proportionate mortality study of workers in the garment industry exposed to formaldehyde. Am J Ind Med. 1985;7:229

35. Stayner LT, Elliott L, Blade L, Keenlyside R, Halperin W. A retrospective cohort mortality study of workers exposed to formaldehyde in the garment industry. Am J Ind Med. 1988;13:667.

36. Coggon D, Harris EC, Poole J, Palmer KT. Extended follow-up of a cohort of British chemical workers exposed to formaldehyde. J Natl Cancer Inst. 2003:95:1608.

37. Gardner MJ, Pannett B, Winter PD, Cruddas AM. A cohort study of workers exposed to formaldehyde in the British chemical industry: an update. $\mathrm{Br} J$ Ind Med. 1993;50:827.

38. Der Simonian R, Laird N. Meta-analysis in clinical trials. Control Clin Trials. 1986;7:177.

39. Egger M, Davey Smith G, Schneider M, Minder C. Bias in meta-analysis detected by a simple, graphical test. BMJ. 1997;315:629.

40. Dutch Expert Committee on Occupational Standards (DECOS). Formaldehyde. Health-based recommended occupational exposure limit. The Hague: Health Council of the Netherlands; 2003.

41. Lu K, Collins LB, Ru H, Bermudez E, Swenberg JA. Distribution of DNA adducts caused by inhaled formaldehyde is consistent with induction of nasal carcinoma but not leukemia. Toxicol Sci. 2010;116:441.

42. Pira E, Romano C, Vecchia C, Boffetta P. Hematologic and cytogenetic biomarkers of leukemia risk from formaldehyde exposure. Carcinogenesis. 2017:38:1251.

43. $\mathrm{Hd} \mathrm{H}$, Casanova $\mathrm{M}$. The implausibility of leukemia induction by formaldehyde: a critical review of the biological evidence on distant-site toxicity. Regul Toxicol Pharmacol. 2004;40:92.

44. Pyatt D, Natelson E, Golden R. Is inhalation exposure to formaldehyde a biologically plausible cause of lymphohematopoietic malignancies? Regul Toxicol Pharmacol. 2008:51:119.

45. Goldstein BD. Hematological and toxicological evaluation of formaldehyde as a potential cause of human leukemia. Hum Exp Toxicol. 2011:30:725.

46. Pontel LB, Rosado IV, Burgos-Barragan G, Garaycoechea JI, Yu R, Arends MJ, et al. Endogenous formaldehyde is a hematopoietic stem cell Genotoxin and metabolic carcinogen. Mol Cell. 2015;60:177.

47. Guerard EJ, Bishop MR. Overview of non-Hodgkin's lymphoma. Dis Mon. 2012;58:208.

48. Siemiatycki J. Risk factors for Cancer in the workplace. Boca Raton: CRC Press; 1991.

\section{Publisher's Note}

Springer Nature remains neutral with regard to jurisdictional claims in published maps and institutional affiliations.

\section{Ready to submit your research? Choose BMC and benefit from:}

- fast, convenient online submission

- thorough peer review by experienced researchers in your field

- rapid publication on acceptance

- support for research data, including large and complex data types

- gold Open Access which fosters wider collaboration and increased citations

- maximum visibility for your research: over $100 \mathrm{M}$ website views per year

At $\mathrm{BMC}$, research is always in progress.

Learn more biomedcentral.com/submissions 